\title{
FORMULASI DAGING KEONG SAWAH DAN TEPUNG PORANG TERHADAP MUTU FISIK DAN SENSORIS BAKSO
}

\author{
[Formulation of Meat Snail and Porang Flour on the Quality of Meatballs] \\ Dewa Nyoman Adi Paramartha*, Yeni Sulastri, Rucitra Widyasari, Zainuri \\ Fakultas Teknologi Pangan dan Agroindustri, Universitas Mataram \\ *email: dewanyoman.adip@unram.ac.id
}

Diterima 18 Desember 2019 / Disetujui 31 Desember 2019

\begin{abstract}
The aim of this study was to examine the formulation of meat snail and porang flour on physical characteristics and sensory acceptance of the meatballs. The design used in this study was a Randomized Block Design (RBD) with 2 treatments, namely the concentration of meat snails and the concentration of porang flour in making meatballs. The treatment of meat snail concentration is 0\%, 20\%, 40\% and 60\% while for porang flour concentration is $0 \%$ and $0.3 \%$. Each experiment was repeated 3 times so that there would be 24 units of trial units. Physical and sensory quality data obtained were analyzed using SPSS with a 5\% BNJ level of significance. Concentration of meat snail has significant effect on physical quality (texture, color ( $L$, a and b)) and sensory quality (color and hedonic texture. Porang flour concentration significantly influences physical quality (colors $L$ and b). Interaction of treatment between the concentration of meat snail and the concentration of porang flour significantly affected physical quality (colors $a$ and b) and the sensory quality of texture hedonically. Treatment of $20 \%$ meat snail concentration with the addition of porang flour $0.3 \%$ is the best treatment. Physical quality values are best treated for texture $3.38 \mathrm{~N}$, color L 42.46, color a 2.92 and color b 16.31. Sensory quality values are best treated for color is rather like and texture likes.
\end{abstract}

Keyword : meatballs, porang flour, meat snail

\begin{abstract}
ABSTRAK
Tujuan dari penelitian ini adalah untuk mengkaji formulasi penggunaan daging keong sawah dan tepung porang terhadap mutu fisik dan sensoris bakso. Rancangan yang digunakan pada penelitian ini adalah Rancangan Acak Kelompok (RAK) dengan 2 perlakuan yaitu konsentrasi daging keong sawah dan konsentrasi tepung porang pada pembuatan bakso. Perlakuan konsentrasi daging keong sawah yaitu 0\%, 20\%, 40\% dan $60 \%$ sedangkan untuk konsentrasi tepung porang yaitu $0 \%$ dan $0,3 \%$. Masing-masing percobaan diulangi sebanyak 3 kali sehingga diperoleh satuan percobaan sebanyak 24 unit percobaan. Data mutu fisik dan sensoris yang diperoleh dianalisa menggunakan SPSS dengan taraf nyata BNJ 5\%. Konsentrasi daging keong sawah berpengaruh nyata terhadap mutu fisik (tekstur, warna ( $L$, a dan $b)$ ), dan mutu sensoris (warna dan tekstur secara hedonik). Konsentrasi tepung porang berpengaruh nyata terhadap mutu fisik (warna $L$ dan $b$ ). Interaksi perlakuan antara konsentrasi daging keong sawah dan konsentrasi tepung porang berpengaruh nyata terhadap mutu fisik (warna a dan b) dan mutu sensoris tekstur secara hedonik. Perlakuan konsentrasi daging keong sawah $20 \%$ dengan penambahan tepung porang $0,3 \%$ merupakan perlakuan yang terbaik. Nilai mutu fisik diperlakuan terbaik untuk tekstur 3,38 N, warna L 42,46, warna a 2,92 dan warna b 16,31 . Nilai mutu sensoris diperlakuan terbaik untuk warna agak suka dan tekstur suka.
\end{abstract}

Kata Kunci : bakso, daging keong sawah, tepung porang

\section{PENDAHULUAN}

Bakso merupakan makanan khas Indonesia yang digemari banyak orang dari berbagai kalangan. Bahan baku utama dalam pembuatan bakso adalah daging sapi, yang ditambah dengan bahan tambahan lainnya seperti tepung, garam, es, Sodium Tripolipospat (STPP) dan berbagai macam bumbu penyedap lainnya. Bahan utama pembuatan bakso selain daging sapi adalah daging ayam dan ikan. Menurut Wibowo (2006), permintaan masyarakat Indonesia untuk produk bakso masih cukup tinggi, mencapai 160.000 ton bakso per tahunnya. Pertumbuhan konsumsi bakso juga dapat mempengaruhi konsumsi protein hewani masyarakat, yang juga dilandasi oleh kebutuhan serta selera konsumen. Pertumbuhan konsumsi daging yang diikuti 
oleh semakin berkembangnya gaya hidup masyarakat juga menjadi salah satu potensi berkembangnya industri makanan cepat saji (Romans et al., 1994). Badan Standarisasi Nasional (2014) mendefinisikan bakso sebagai produk olahan daging yang dibuat dari daging hewan ternak yang dicampur pati dan bumbubumbu, dengan atau tanpa penambahan bahan pangan lainnya, dan atau bahan tambahan pangan yang diizinkan, yang berbentuk bulat atau bentuk lainnya dan dimatangkan.

Keong sawah yang disebut juga dengan fresh water snail, banyak ditemukan di Indonesia pada kawasan persawahan maupun aliran sungai, yang dimanfaatkan sejak dahulu oleh masyarakat Indonesia sebagai salah satu sumber protein dalam bahan makanan tradisional. Keong sawah terbukti secara ilmiah memiliki kandungan gizi yang cukup tinggi. Keong sawah mengandung $15 \%$ protein, $2,4 \%$ lemak, kadar abu 24\%. Selain itu, keong sawah juga mengandung mineral yang penting untuk tubuh, yang dimana kandungan tertinggi dari keong sawah adalah kalsium (Oktasari; 2015).

Hingga saat ini, penggunaan daging keong sawah sebagai bahan pembuatan bakso, belum lazim dan perlu dikembangkan, karena keong sawah masih dianggap sebagai hama perusak tanaman di sawah. Sejak kedatangan keong sawah di Indonesia, keong sawah telah menimbulkan penurunan produksi pertanian di berbagai daerah. Sebagai hama potensial tanaman padi, keong sawah jika dikelola dapat menjadi suatu komoditas prospektif untuk meningkatkan taraf hidup petani dan meningkatkan gizi masyarakat. Oleh karena itu, perlu adanya penelitian pembuatan bakso berbasis daging keong sawah, sehingga dapat meningkatkan nilai ekonomi dan konsumsi protein masyarakat. Muchtadi (2010) juga menyampaikan, dengan kandungan asam amino dan daya cernanya yang cukup baik, protein hewani memiliki nilai biologis yang lebih baik jika dibandingkan dengan protein nabati.

Oleh karena potensi keong sawah sebagai sumber protein yang tinggi pada pembuatan bakso, maka semakin banyak penelitian yang mengkaji tentang pemanfaatan keong sawah untuk menguji daya terima dan kandungan protein bakso keong sawah (Rauf, 2011), penggunaannya pada pembuatan nugget (Oktasari, 2015), serta penerimaan dan kandungan gizinya pada produk gyoza (Permatasari dan Adi, 2018). Keong sawah juga telah banyak dimanfaatkan sebagai bahan olahan makanan, seperti yang disampaikan oleh Tanjung et al., (2013) dimana pemanfaatan daging tutut (keong sawah) berpotensi untuk dikembangkan menjadi produk bernilai tambah seperti bakso, kripik tutut, kerupuk tutut, serta sate tutut. Namun demikian, belum ada penelitian lebih lanjut yang terkait dengan pengembangan produk bakso terhadap pengaruh daging keong sawah dalam formulasi produk bakso, dan uji organoleptiknya.

Umbi porang (Amorphophallus muelleri Blume) memiliki senyawa glukomanan yang memiliki fungsi hampir sama dengan STPP yaitu mampu mengikat air sampai 200 kali lipat beratnya (Sood et al., 2008). Glukomanan juga memiliki kemampuan sebagai gelling agent yang dapat digunakan sebagai bahan pengikat pada produk makanan. Kemampuan mengikat air tepung porang lebih tinggi dibandingkan dengan tepung tapioka, hal ini mengakibatkan penggunaan tepung porang akan lebih sedikit dari penggunaan tepung tapioka (Akesowan, 2007). Penelitian sebelumnya yang disampaikan oleh Suwati (2007), mengenai proporsi penambahan tepung tapioka dan tepung terigu dalam pembuatan bakso ikan tongkol berpengaruh nyata terhadap kadar air, kadar protein. Sedangkan menurut penelitian Sudarwati (2007), penambahan tepung tapioka dan tepung sagu berpengaruh nyata terhadap kadar air, kadar abu, kadar protein dan kadar lemak.

Berdasarkan hal tersebut telah dilakukan penelitian formulasi daging keong sawah dan tepung porang terhadap produk bakso untuk mendapatkan formulasi bakso keong sawah yang terbaik dan dapat diterima oleh konsumen. 
Versi Online:

http://www.profood.unram.ac.id/index.php/profood e-ISSN: 2443-3446

\section{BAHAN DAN METODE}

\section{Bahan dan Alat}

Bahan yang digunakan dalam proses pembuatan bakso keong sawah antara lain daging keong sawah (Pila ampullacea), daging sapi, tepung tapioka, tepung porang, garam, bawang putih dan bumbu-bumbu lainnya.

Alat yang digunakan selama proses penelitian antara lain food processor, panci, pisau dan kompor. Alat yang digunakan untuk penelitian atau analisis antara lain penetrometer, colorimeter serta seperangkat alat pengujian organoleptik.

\section{Metode}

Penelitian ini menggunakan Rancangan Acak Kelompok (RAK) dengan 2 faktor yaitu konsentrasi daging keong sawah dan konsentrasi tepung porang pada pembuatan bakso. Perlakuan konsentrasi tepung porang yaitu $0 \%$ dan $0,3 \%$ sedangkan untuk konsentrasi daging keong sawah yaitu $0 \%$, $20 \%$, 40\% dan 60\%. Masing masing percobaan dilakukan ulangan sebanyak 3 kali sehingga diperoleh 24 unit percobaan.

\section{Pelaksanaan Penelitian Pembuatan Bakso Keong Sawah}

\section{Persiapan Daging Keong}

\section{Sortasi}

Keong sawah disortasi terlebih dahulu untuk menghilagkan kotoran dan cangkang yang menempel pada daging keong.

\section{Pencucian dan penirisan}

Tahap selanjutnya adalah pencucian daging keong. Pencucian dilakukan untuk
Pro Food (Jurnal IImu dan Teknologi Pangan)

Vol 5 No. 2 November 2019

ISSN: 2443-1095

memperoleh daging keong yang bersih. Kemudian dilakukan penirisan.

\section{Perebusan}

Perebusan keong dilakukan selama 1 jam. Hal ini dilakukan agar diperoleh daging keong yang empuk dan memudahkan dalam proses pencampuran.

\section{Persiapan Daging Sapi Segar}

Pemisahan Lemak dan serat daging sapi segar

Tahapan ini dilakukan untuk memperoleh dagingnya saja. Supaya mempermudah dalam pencampuran dan pembentukan adonan.

\section{Pemotongan}

Pemotongan daging berbentuk cubes dengan ukuran $3 \times 3 \mathrm{~cm}$. Pemotongan daging ditujukan untuk mengecilkan ukuran daging, sehingga memudahkan dalam proses penggilingan.

\section{Penimbangan}

Daging keong yang sudah matang dan daging sapi segar yang sudah diperkecil ukurannya serta bahan tambahan atau bumbubumbu yang telah disiapkan kemudian ditimbang agar sesuai dengan unit perlakuan yang akan diujikan. Untuk satu unit perlakuan menggunakan 100 gram campuran daging sapi dan daging keong sawah. Komposisi adonan bakso dengan pencampuran daging keong sawah dan tepung porang dapat dilihat pada Tabel 1.

Tabel 1. Komposisi Adonan Bakso Keong Sawah

\begin{tabular}{lcrrrrrrr}
\hline \multirow{1}{*}{ Bahan - Bahan } & \multicolumn{8}{c}{ Kandungan (gram) } \\
\cline { 2 - 10 } & S1P1 & S1P2 & S2P1 & S2P2 & S3P1 & S3P2 & S4P1 & S4P2 \\
\hline Daging sapi & 100 & 100 & 80 & 80 & 60 & 60 & 40 & 40 \\
\hline Daging Keong Sawah & 0 & 0 & 20 & 20 & 40 & 40 & 60 & 60 \\
\hline Tepung Porang & 0 & 0,3 & 0 & 0,3 & 0 & 0,3 & 0 & 0,3 \\
Tepung Tapioka & 20 & 20 & 20 & 20 & 20 & 20 & 20 & 20 \\
Garam & 2 & 2 & 2 & 2 & 2 & 2 & 2 & 2 \\
Bawang Putih & 1 & 1 & 1 & 1 & 1 & 1 & 1 & 1 \\
Bawang merah & 1 & 1 & 1 & 1 & 1 & 1 & 1 & 1 \\
Air Es & 5 & 5 & 5 & 5 & 5 & 5 & 5 & 5 \\
\hline Total Adonan & $\mathbf{1 2 9}$ & $\mathbf{1 2 9 , 3}$ & $\mathbf{1 2 9}$ & $\mathbf{1 2 9 , 3}$ & $\mathbf{1 2 9}$ & $\mathbf{1 2 9 , 3}$ & $\mathbf{1 2 9}$ & $\mathbf{1 2 9 , 3}$ \\
\hline
\end{tabular}


Versi Online:

http://www.profood.unram.ac.id/index.php/profood e-ISSN: 2443-3446

\section{Persiapan Pembentukan Adonan Penggilingan}

Daging sapi dan daging keong kemudian digiling menggunakan food processor untuk memudahkan dalam pencampuran adonan.

\section{Pencampuran}

Pencampuran adonan dilakukan dengan berbagai perlakuan menggunakan food processor. Pencampuran bahan dilakukan dengan tujuan untuk memperoleh adonan yang homogen dan memudahkan dalam pencetakan bola-bola bakso.

\section{Pencetakan}

Setelah memperoleh adonan yang homogen, adonan dibentuk menjadi bola-bola bakso yang siap untuk direbus. Pencetakan adonan menjadi bola-bola bakso dilakukan dengan tangan yang telah dibungkus dengan kantong plastik atau sarung tangan plastik. Pencetakan bola-bola bakso dilakukan dengan cara adonan diambil dengan sendok makan lalu dibulatkan dengan kedua tangan sehingga terbentuk bola-bola bakso. Ukuran bola bakso diusahakan seragam sesuai dengan yang diinginkan.

\section{Perebusan}

Bola bakso yang sudah terbentuk langsung dimasukkan dalam air yang mendidih $\left(100^{\circ} \mathrm{C}\right)$ hingga matang. Jika bola bakso sudah mengapung di permukaan air berarti bakso sudah matang dan dapat diangkat. Kematangan bakso juga dapat diperiksa dengan melihat bagian dalam bakso, jika diiris bekas irisan bakso yang sudah matang tampak mengkilat. Biasanya perebusan bakso memerlukan waktu 15 menit.

\section{HASIL DAN PEMBAHASAN}

\section{Hasil Analisa Data}

Data mutu fisik dan sensoris yang diperoleh dianalisa menggunakan SPSS dengan taraf nyata BNJ 5\%. Hasil analisa data mutu fisik dapat dilihat pada Tabel 2-3 dan mutu sensoris dapat dilihat pada Tabel 4-5.
Tabel 2. Purata Hasil Pengamatan Pengaruh Konsentrasi Daging Keong Sawah dan Konsentrasi Tepung Porang terhadap Mutu Fisik Bakso Keong Sawah

\begin{tabular}{|c|c|c|c|c|c|}
\hline \multirow{3}{*}{$\mathbf{F}_{\mathbf{1}}$} & \multirow{3}{*}{$\mathbf{F}_{\mathbf{2}}$} & \multicolumn{4}{|c|}{ Parameter Fisik } \\
\hline & & \multirow{2}{*}{$\begin{array}{l}\text { Tekstur } \\
\text { (N) }\end{array}$} & \multicolumn{3}{|c|}{ Warna } \\
\hline & & & (L) & (a) & (b) \\
\hline \multirow{2}{*}{$\mathrm{S}_{1}$} & $P_{1}$ & 4,49 & 47,92 & 4,05 & 17,31 \\
\hline & $\mathrm{P}_{2}$ & 4,38 & 44,86 & 5,11 & 14,74 \\
\hline \multirow{2}{*}{$\mathrm{S}_{2}$} & $\mathrm{P}_{1}$ & 3,78 & 45,03 & 3,07 & 16,60 \\
\hline & $\mathrm{P}_{2}$ & 3,38 & 42,46 & 2,93 & 16,31 \\
\hline \multirow{2}{*}{$\mathrm{S}_{3}$} & $\mathrm{P}_{1}$ & 2,61 & 40,87 & 1,84 & 14,68 \\
\hline & $\mathrm{P}_{2}$ & 2,95 & 38,53 & 1,69 & 12,86 \\
\hline \multirow{2}{*}{$\mathrm{S}_{4}$} & $P_{1}$ & 2,18 & 39,80 & 1,70 & 12,19 \\
\hline & $\mathrm{P}_{2}$ & 2,07 & 41,44 & 1,34 & 12,38 \\
\hline
\end{tabular}

Tabel 3. Pengaruh Konsentrasi Daging Keong Sawah dan Konsentrasi Tepung Porang terhadap Mutu Fisik Bakso Keong Sawah

\begin{tabular}{|c|c|c|c|}
\hline \multirow{3}{*}{ Parameter } & \multicolumn{3}{|c|}{ Signifikansi } \\
\hline & \multicolumn{2}{|c|}{ Konsentrasi } & \multirow[b]{2}{*}{$\begin{array}{c}\text { Interaksi } \\
\text { S*P }\end{array}$} \\
\hline & $\begin{array}{c}\text { Daging } \\
\text { Keong } \\
\text { Sawah (S) }\end{array}$ & $\begin{array}{l}\text { Tepung } \\
\text { Porang } \\
\text { (P) }\end{array}$ & \\
\hline Tekstur (N) & $\mathrm{S}$ & NS & NS \\
\hline Warna (L) & $\mathrm{S}$ & $\mathrm{S}$ & NS \\
\hline Warna (a) & $\mathrm{S}$ & NS & $\mathrm{S}$ \\
\hline Warna (b) & $\mathrm{S}$ & $\mathrm{S}$ & $\mathrm{S}$ \\
\hline $\begin{aligned} \text { Keterangan: } & \text { S } \\
& (*)\end{aligned}$ & \multicolumn{3}{|c|}{$\begin{array}{l}=\text { Signifikan (Berbeda Nyata) } \\
=\text { Non-Signifikan (Tidak Berbeda Nyata) } \\
=\text { Taraf Nyata } 5 \%\end{array}$} \\
\hline
\end{tabular}

Tabel 4. Purata Hasil Pengamatan Pengaruh Konsentrasi Daging Keong Sawah dan Konsentrasi Tepung Porang terhadap Mutu Sensoris Bakso Keong Sawah Secara Hedonik

\begin{tabular}{|c|c|c|c|}
\hline \multirow{2}{*}{$\mathbf{F}_{\mathbf{1}}$} & \multirow{2}{*}{$\mathbf{F}_{2}$} & \multicolumn{2}{|c|}{ Parameter Sensoris } \\
\hline & & Warna & Tekstur \\
\hline \multirow{2}{*}{$\mathrm{S}_{1}$} & $P_{1}$ & 3,22 & 2,93 \\
\hline & $\mathrm{P}_{2}$ & 3,37 & 3,22 \\
\hline \multirow{2}{*}{$\mathrm{S}_{2}$} & $\mathrm{P}_{1}$ & 3,11 & 2,85 \\
\hline & $\mathrm{P}_{2}$ & 3,26 & 3,59 \\
\hline \multirow{2}{*}{$\mathrm{S}_{3}$} & $\mathrm{P}_{1}$ & 2,96 & 3,19 \\
\hline & $\mathrm{P}_{2}$ & 3,07 & 3,07 \\
\hline \multirow{2}{*}{$\mathrm{S}_{4}$} & $P_{1}$ & 2,44 & 3,15 \\
\hline & $\mathrm{P}_{2}$ & 2,52 & 2,78 \\
\hline
\end{tabular}

Keterangan : Faktor $1\left(F_{1}\right)$, Faktor $2\left(F_{2}\right)$, Konsentrasi Daging Keong Sawah 0\% $\left(\mathrm{S}_{1}\right), 20 \%\left(\mathrm{~S}_{2}\right), 40 \%\left(\mathrm{~S}_{3}\right)$ dan $60 \%\left(\mathrm{~S}_{4}\right)$, Konsentrasi Tepung Porang 0\% $\left(P_{1}\right)$ dan 0,3\% $\left(P_{2}\right)$ 
Versi Online:

http://www.profood.unram.ac.id/index.php/profood e-ISSN: 2443-3446

Tabel 5. Pengaruh Konsentrasi Daging Keong Sawah dan Konsentrasi Tepung Porang terhadap Mutu Sensoris Bakso Keong Sawah

\begin{tabular}{|c|c|c|c|}
\hline \multirow{3}{*}{ Parameter } & \multicolumn{3}{|c|}{ Signifikansi } \\
\hline & \multicolumn{2}{|c|}{ Konsentrasi } & \multirow[b]{2}{*}{$\begin{array}{c}\text { Interaksi } \\
\mathbf{S * P}\end{array}$} \\
\hline & $\begin{array}{c}\text { Daging } \\
\text { Keong } \\
\text { Sawah (S) }\end{array}$ & $\begin{array}{c}\text { Tepung } \\
\text { Porang } \\
\text { (P) }\end{array}$ & \\
\hline Warna & S & NS & NS \\
\hline Tekstur & NS & NS & S \\
\hline $\begin{aligned} & \text { Keterangan: } \text { S } \\
& \text { NS } \\
&(*)\end{aligned}$ & $\begin{array}{l}=\text { Signifika } \\
=\text { Non-Sig } \\
=\text { Taraf Ny }\end{array}$ & $\begin{array}{l}\text { erbeda N } \\
\text { in (Tidak } \\
\%\end{array}$ & eda Nyata) \\
\hline
\end{tabular}

\section{Pembahasan}

\section{Tekstur (Newton)}

Tekstur merupakan salah satu indikator untuk menentukan kualitas fisik bakso keong sawah. Dalam Standar Nasional Indonesia (SNI) 3818-2014 bakso daging, salah satu syarat mutu bakso adalah teksturnya kenyal. Menurut Hardoko et al. (2018), nilai tekstur dalam satuan newton menunjukan semakin besar nilai yang dihasilkan maka semakin keras tekstur produk. Pada parameter tekstur konsentrasi daging keong sawah $0 \%\left(\mathrm{~S}_{1}\right)$ tidak berbeda nyata dengan $20 \%\left(\mathrm{~S}_{2}\right)$, namun berbeda nyata dengan $40 \%\left(\mathrm{~S}_{3}\right)$ dan $60 \%\left(\mathrm{~S}_{4}\right)$ serta $40 \%\left(\mathrm{~S}_{3}\right)$ tidak berbeda nyata dengan $60 \% \quad\left(\mathrm{~S}_{4}\right)$. Pengaruh konsentrasi tepung porang $(P)$ yang meliputi $0 \%\left(P_{1}\right)$ dan 0,3\% $\left(P_{2}\right)$ memberikan pengaruh yang tidak berbeda nyata terhadap tekstur bakso keong sawah. Pengaruh konsentrasi daging keong sawah terhadap tekstur bakso keong sawah dapat dilihat pada Gambar 1.

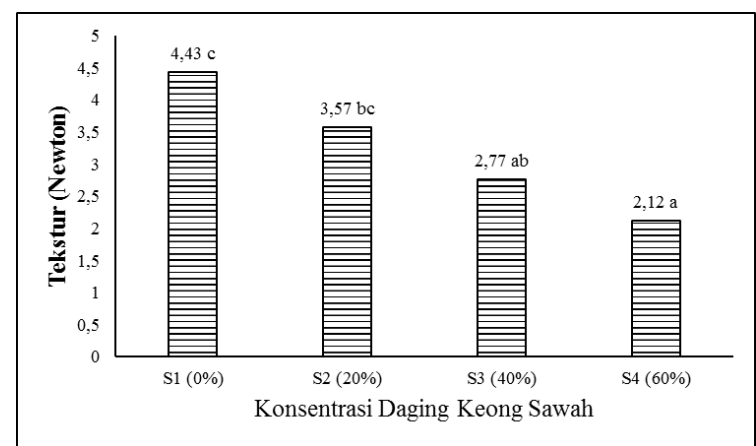

Gambar 1. Pengaruh Konsentrasi Daging Keong Sawah terhadap Tekstur Bakso Keong Sawah
Pro Food (Jurnal Ilmu dan Teknologi Pangan)

Vol 5 No. 2 November 2019

ISSN: 2443-1095

Gambar 1 menunjukkan nilai tekstur yang terus menurun atau semakin kenyal dengan semakin tinggi konsentrasi daging keong sawah yang ditambahkan. Hal ini dipengaruhi oleh enzim proteolitik yang terdenaturasi. Pada saat mendidih enzim sudah berhenti bekerja atau inaktif, sehingga protein tidak mengalami proses pemecahan lebih lanjut, sehingga hasil pemecahan yang dilakukan oleh enzim proteolitik tetap protein namun dalam bentuk yang lebih sederhana. Menurut Mahbub (2012), kekenyalan pada bakso terbentuk pada saat pemasakan dimana protein akan mengalami denaturasi dan molekul-molekulnya akan berkembang seiring dengan temperatur air yang digunakan untuk proses pemasakan. Menurut Silaban (2009), mengemukakan bahwa kualitas dari daging dipengaruhi oleh cara memasaknya. Daging yang terlalu lama dalam proses pemanasan akan menyebabkan kandungan proteinnya berkurang. Enzim proteolitik merupakan enzim yang dapat memecah protein sehingga dapat melunakkan daging. Enzim proteolitik akan menghidrolisis daging sehingga daging akan mengendur dan akan menjadi lebih empuk.

Menurut Kusnandar (2010), protein yang terdenaturasi oleh panas hanya mengalami perubahan struktur tersier protein namun tidak mengalami perubahan susunan asam aminonya. Denaturasi protein adalah terjadinya modifikasi sekunder, tersier dan kuarter dari protein tanpa menyebabkan pemutusan ikatan peptide dan perubahan sekuen asam amino pada struktur protein. Denaturasi protein dapat menyebabkan bahan pangan yang mengandung protein mengalami perubahan tekstur (misalnya membentuk gel), kehilangan daya ikat air atau mengalami pengerutan.

Kaitan lainnya yang mempengaruhi tekstur bakso yaitu kandungan lemak. Menurut Gunawan (2013), lemak atau marbling daging dapat mempengaruhi tesktur daging karena dipengaruhi oleh banyak atau sedikitnya lemak dalam daging yang akan membuat tesktur daging menjadi lebih empuk. Menurut Risjad (1996), daging keong sawah memiliki kadar lemak sebesar 2,4\%. Menurut Depkes RI 
(1995), daging sapi memiliki kadar lemak sebesar $14,0 \%$. Dari hal tersebut, lemak daging keong sawah lebih rendah daripada lemak daging sapi. Semakin tinggi kadar lemak maka teksturnya akan semakin kenyal, sebaliknya semakin rendah kadar lemak maka teksturnya semakin tidak kenyal.

Tabel 3 menunjukkan pengaruh konsentrasi tepung porang yang digunakan atau ditambahkan terlalu sedikit sehingga tidak menimbulkan perubahan tekstur yang berbeda. Kekenyalan bakso daging keong sawah pada penambahan tepung porang berhubungan dengan glukomanan yang menyebabkan terbentuknya gel akibat pemanasan atau proses pengolahan bakso. Hal ini dikarenakan tepung porang memiliki sifat mengikat air dalam adonan sehingga terjadi sifat elastis dalam adonan yang menyebabkan bakso menjadi kenyal. Tepung porang memiliki kandungan glukomanan yang dapat menyebabkan perubahan tekstur pada produk. Menurut Widjanarko (2014), tepung porang memiliki kandungan glukomanan sebesar 43,98\%. Menurut Utami $d k k$. (2017) dalam penelitian penggunaan glukomanan pada nugget ayam, glukomanan berfungsi sebagai binding agents yang menyebabkan perubahan sifat gel 3 dimensi pada produk atau menyebabkan kekenyalan semakin kuat. Menurut Huang, $d k$. (2002), kekenyalan bakso ditentukan oleh tingkat kerapatan struktur matriks yang terbentuk akibat pemanasan. Semakin tinggi kerapatan struktur matriks, maka semakin tinggi nilai kekenyalan bakso.

\section{Warna L}

Warna memegang peranan penting terhadap karakteristik bahan maupun produk pangan. Warna (L) adalah derajat kecerahan produk. Menurut (Engelen; 2018) warna L menyatakan parameter kecerahan (warna akromatis, 0: hitam sampai 100: putih). Pada parameter warna $(\mathrm{L})$ konsentrasi daging keong sawah $0 \%\left(S_{1}\right)$ berbeda nyata dengan $20 \%$ $\left(\mathrm{S}_{2}\right), 40 \%\left(\mathrm{~S}_{3}\right)$ dan $60 \%\left(\mathrm{~S}_{4}\right)$, sedangkan $40 \%$ $\left(\mathrm{S}_{3}\right)$ tidak berbeda nyata dengan $60 \%\left(\mathrm{~S}_{4}\right)$. Pengaruh konsentrasi tepung porang $(P)$ yang meliputi $0 \%\left(P_{1}\right)$ dan 0,3\% $\left(P_{2}\right)$ memberikan pengaruh yang berbeda nyata terhadap warna L bakso keong sawah. Pengaruh Konsentrasi daging keong sawah dan konsentrasi tepung porang terhadap warna $L$ bakso keong sawah masing-masing dapat dilihat pada Gambar 2 dan Gambar 3.

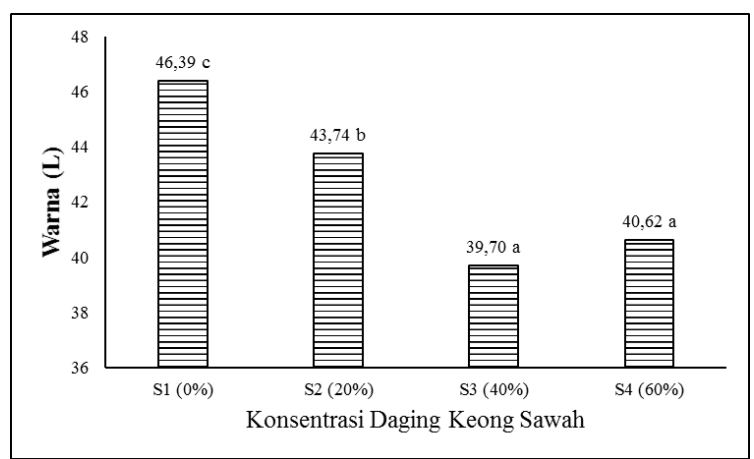

Gambar 2. Pengaruh Konsentrasi Daging Keong Sawah terhadap Warna L Bakso Keong Sawah

Gambar 2 menunjukkan nilai warna L yang semakin kecil atau semakin gelap dengan semakin tinggi konsentrasi daging keong sawah yang ditambahkan. Menurut Wibowo (2006) dalam Sidik (2013), warna pada bakso bervariasi namun idealnya berwarna putih keabu-abuan. Kriteria bakso yang baik yaitu berwarna cokelat muda cerah, sedikit agak kemerahan, cokelat muda hingga cokelat muda agak keputihan atau abu-abu, warna tersebut merata tanpa warna lain mengganggu. Namun, bakso keong sawah yang didapatkan cenderung semakin gelap dengan semakin tinggi penambahan daging keong sawah. Hal ini disebabkan warna yang timbul dari penambahan daging keong sawah merupakan warna putih kecokelatan dan kehitaman yang diduga mengandung melanin, dibanding dengan warna bakso tanpa daging keong sawah yang tampak kecokelatan. Menurut Hill (2006), melanin merupakan pigmen warna hitam yang lazim terdapat pada non daging. Melanin umumnya tidak ditemukan pada jaringan otot, tetapi terdapat pada jaringan kulit. Sel melanosit menghasilkan melanin yang merupakan penentu warna kulit. 


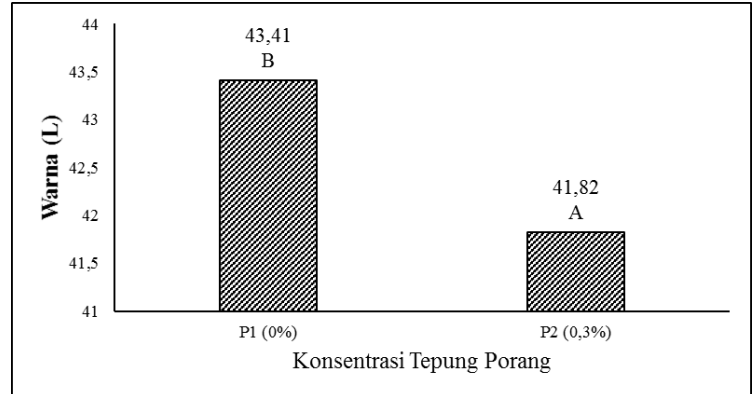

Gambar 3. Grafik Pengaruh Konsentrasi Daging Keong Sawah terhadap Warna L Bakso Keong Sawah

Gambar 3 menunjukkan semakin tinggi penambahan konsentrasi tepung porang maka warna bakso daging keong sawah yang dihasilkan cenderung lebih gelap yang ditandai dengan semakin kecilnya warna L. Menurut Anggraeni dkk. (2014), tepung porang berwarna krem sampai cokelat terang. Namun, bakso keong sawah yang didapatkan cenderung semakin gelap dengan diberi penambahan tepung porang. Hal ini disebabkan warna yang timbul dari penambahan tepung porang berwarna krem semakin gelap, yang diduga molekul air terperangkap dalam struktur gel. Tepung porang mengandung glukomanan yang memiliki kemampuan yang sama dengan gelatin yaitu bersifat sebagai pembentuk gel (gelling agent).

Menurut Rahmi, dkk. (2012), pada saat dilakukan pemasakan pada suhu $90^{\circ} \mathrm{C}$, maka panas akan membuka ikatan-ikatan molekul gelatin. Gelatin mempunyai sifat reversibel yaitu apabila dipanaskan akan mencair dan membentuk sol. Jika didinginkan sol akan berubah menjadi gel dan gel tersebut lebih mirip padatan dari pada cairan. Menurut Glicksman (1969) dalam Herutami (2002), Molekul-molekul tersebut mulai mengurai dan terjadi ikatan-ikatan silang antara molekulmolekul yang berdekatan sehingga terbentuk satu pertautan atau jaringan molekul-molekul yang saling bertautan sehingga menyebabkan air yang semula bebas mengalir menjadi terperangkap didalam struktur tersebut. Menurut Ramdani (2018), proporsi bahan pembentuk gel yang semakin besar menyebabkan makin banyak cairan yang terperangkap dalam gel dan ikatan antara pembentuk gel dengan cairan lebih rapat yang menyebabkan warna menjadi lebih gelap. Penyebab lainnya menurut Winarno (2002) bahwa warna abu-abu gelap pada bakso ini dapat disebabkan oleh adanya reaksi Maillard antara gula pereduksi dari tepung glukosa dengan gugus amina primer.

\section{Warna a}

Warna a adalah warna kromatik campuran merah hijau ditunjukkan oleh nilai a ( $a+=0-100$ untuk warna merah, $a-=0-(-80)$ untuk warna hijau (Engelen; 2018). Interaksi perlakuan antara konsentrasi daging keong sawah dan konsentrasi tepung porang memberikan pengaruh yang berbeda nyata terhadap warna a bakso keong sawah (Gambar 4).

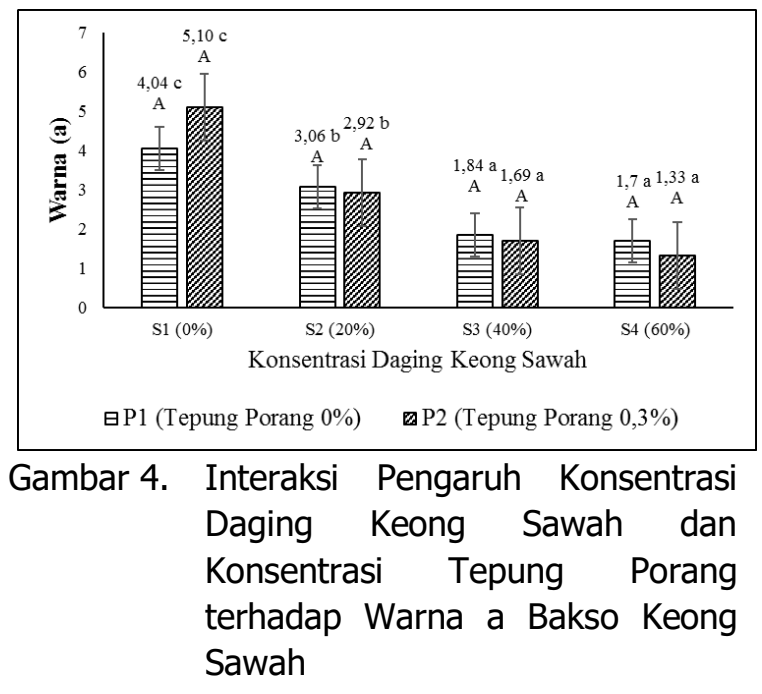

Gambar 4 menunjukkan nilai warna a semakin menurun yang mengindikasikan warna semakin tidak merah pada bakso keong sawah. Warna merah disebabkan karena warna dari daging keong sawah yang berhubungan dengan kapiler darah bukan penyebab dari warna tepung porang. Warna dari tepung porang berwarna krem. Warna dari daging keong sawah berwarna putih kecokelatan dan kehitaman. Daging keong sawah diduga mengandung melanin (pigmen warna hitam). Menurut Purnamasari (2009), fibromelanosis merupakan efek kombinasi pigmen hitam (melanin) pada kulit dan merah pada darah dipembuluh kapiler. Semakin tinggi penambahan daging keong sawah maka warna 
semakin tidak merah. Jika dibandingkan warna merah pada daging sapi berhubungan dengan mioglobin daging. Menurut Sudrajat (2007) dalam Sidik (2013), warna bakso sangat dipengaruhi oleh warna daging yang berhubungan dengan kandungan mioglobin daging. Semakin tinggi mioglobinnya maka semakin merah atau merah gelap warna pada daging.

\section{Warna b}

Warna b adalah warna kromatik campuran biru kuning ditunjukkan oleh nilai $b$ $(b+=0-70$ untuk warna kuning, $b-=0-(-70)$ untuk warna biru (Engelen; 2018). Interaksi perlakuan antara konsentrasi daging keong sawah dan konsentrasi tepung porang memberikan pengaruh yang berbeda nyata terhadap warna $\mathrm{b}$ bakso keong sawah. Interaksi perlakuan konsentrasi daging keong sawah $0 \%\left(\mathrm{~S}_{1}\right)$ dan konsentrasi tepung porang $0 \%\left(P_{1}\right)$ berbeda nyata dengan $0 \%\left(S_{1}\right)$ dan konsentrasi tepung porang $0,3 \%\left(\mathrm{P}_{2}\right)$ dan berinteraksi yang berbeda nyata dengan konsentrasi daging keong sawah $40 \%\left(\mathrm{~S}_{3}\right)$ dan konsentrasi tepung porang $0 \%\left(\mathrm{P}_{1}\right)$ yang berbeda nyata dengan $40 \% \quad\left(\mathrm{~S}_{3}\right)$ dan konsentrasi tepung porang $0,3 \%\left(\mathrm{P}_{2}\right)$ dan berinteraksi yang berbeda nyata dengan konsentrasi daging keong sawah $60 \%\left(\mathrm{~S}_{4}\right)$ dan konsentrasi tepung porang $0 \%\left(\mathrm{P}_{1}\right)$ yang berbeda nyata dengan $60 \% \quad\left(\mathrm{~S}_{4}\right)$ dan konsentrasi tepung porang $0,3 \%\left(\mathrm{P}_{2}\right)$ terhadap warna $b$ bakso keong sawah (Gambar 5).

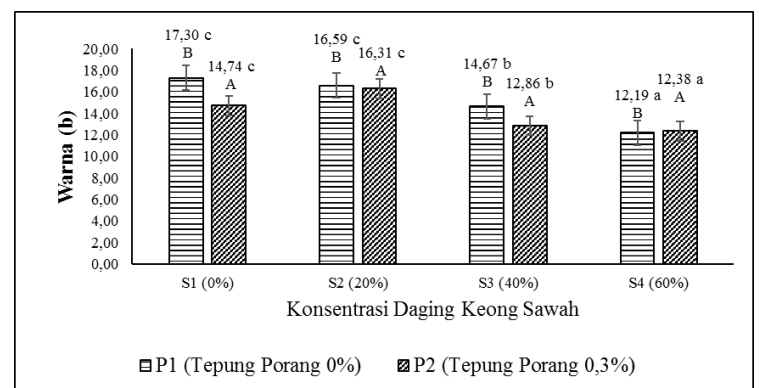

Gambar 5. Grafik Interaksi Pengaruh Konsentrasi Daging Keong Sawah dan Konsentrasi Tepung Porang terhadap Warna b Bakso Keong Sawah

Gambar 5 menunjukkan nilai warna b semakin menurun yang mengindikasikan warna semakin tidak kuning pada bakso keong sawah. Warna kuning disebabkan dari warna tepung porang bukan penyebab dari warna daging keong sawah. Warna daging keong sawah berwarna putih kecokelatan dan kehitaman. Warna tepung porang merupakan bahan baku pendukung pembuatan bakso keong sawah yaitu berwarna krem. Menurut Sumarwoto (2005), warna dalam umbi porang berwarna kuning kecokelatan dan warna luar umbi berwarna kuning kecokelatan-krem.

\section{Warna Hedonik}

Warna merupakan atribut organoleptik yang pertama dilihat oleh konsumen dalam membeli atau mengkonsumsi suatu produk. Warna harus dapat mewakili citarasa produk (Apandi et al.; 2016). Pengaruh konsentrasi daging keong sawah (S) memberikan pengaruh yang berbeda nyata terhadap warna bakso secara hedonik. Pada parameter warna konsentrasi daging keong sawah $0 \%\left(\mathrm{~S}_{1}\right)$ tidak berbeda nyata dengan $20 \%\left(\mathrm{~S}_{2}\right)$ dan $40 \%\left(\mathrm{~S}_{3}\right)$ namun berbeda nyata dengan konsentrasi $60 \%$ $\left(\mathrm{S}_{4}\right)$ (Gambar 6). Pengaruh konsentrasi tepung porang $(P)$ memberikan pengaruh yang tidak berbeda nyata terhadap warna bakso keong sawah secara hedonik.

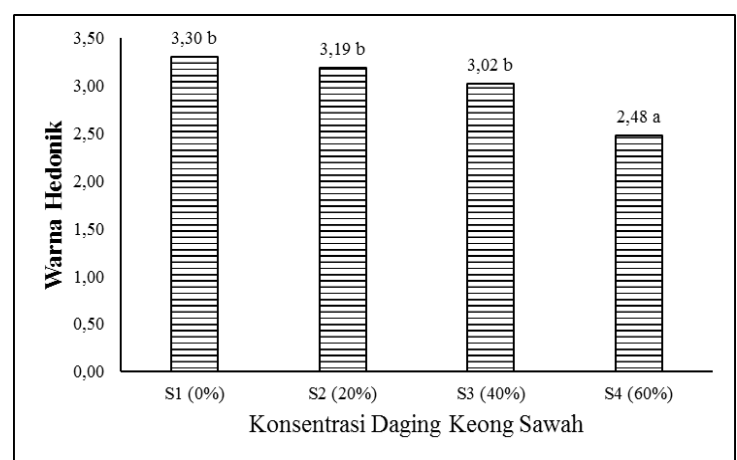

Gambar 6. Grafik Pengaruh Konsentrasi Daging Keong Sawah terhadap Warna Hedonik Bakso Keong Sawah

Gambar 6 menunjukkan semakin tinggi konsentrasi daging keong sawah maka semakin gelap warna yang dihasilkan bakso keong sawah. Nilai rerata rentang yang dihasilkan yaitu 2,48 (tidak suka) hingga 3,30 (agak suka) terhadap warna bakso keong sawah. Panelis cenderung tidak suka warna bakso keong sawah karena berwarna kehitaman, sedangkan 
panelis yang cenderung agak suka warna bakso keong sawah karena berwarna abu-abu yang tidak terlalu gelap. Hal ini dipengaruhi oleh warna daging keong sawah yang berwarna putih kecokelatan dan kehitaman. Semakin tinggi penambahan daging keong sawah maka semakin gelap warna bakso yang dihasilkan. Hal ini sesuai dengan semakin tinggi konsentrasi daging sawah maka warna kecerahan (L) semakin menurun. Menurut hasil penelitian Hermanianto (2002), warna bakso yang disukai masyarakat adalah warna abu-abu yang tidak terlalu gelap atau tidak terlalu pucat.

Tabel 5 menunjukkan pengaruh konsentrasi tepung porang yang digunakan atau ditambahkan terlalu sedikit sehingga tidak menimbulkan perubahan warna yang berbeda. Nilai rerata secara keseluruhan berada pada rentang 2,93-3,05 (agak suka) oleh panelis terhadap warna bakso keong sawah. Panelis cenderung agak suka warna bakso keong sawah karena berwarna abu-abu yang tidak terlalu gelap. Hal tersebut berhubungan dengan pengaruh molekul air yang terperangkap dalam struktur gel. Tepung porang mempunyai kandungan glukomanan yang memiliki sifat higroskopis dan pembentuk gel. Menurut Yuwono (1998) dalam Sugiarso et al. (2015), semakin banyak molekul air yang terperangkap dalam struktur gel, maka ikatan antara pembentuk gel dengan air semakin rapat sehingga warna yang dihasilkan lebih gelap.

\section{Tekstur Hedonik}

Tekstur merupakan salah satu sifat dari suatu bahan atau produk pangan yang dapat dirasakan atau dicicipi melalui sentuhan kulit (indra peraba) ataupun pencicipan. Menurut Cato $d k k$. (2015), tekstur merupakan kombinasi yang tidak dipisahkan dari rasa. Kombinasi dari rasa dan tekstur yang baik dalam pengolahan bahan pangan merupakan kunci dalam meraih kesukaan dari konsumen. Gambar 7 menunjukkan interaksi antara konsentrasi daging keong sawah dan tepung porang terhadap tekstur hedonik semakin menurun atau semakin agak suka dengan semakin tinggi konsentrasi daging keong sawah dan tepung porang yang ditambahkan. Nilai rerata tekstur hedonik secara keseluruhan berada pada rentang 2,78 (agak suka) hingga 3,59 (suka). Panelis agak suka terhadap tekstur bakso keong sawah karena agak kenyal sedangkan panelis suka terhadap tekstur bakso keong sawah karena kenyal. Hal ini diduga dipengaruhi oleh kandungan glukomanan, protein dan lemak pada daging keong sawah. Menurut Panjaitan $d k k$. (2017), umbi porang memiliki kandungan glukomanan yang memiliki fungsi sebagai pengenyal, pembentuk tekstur dan pengental makanan. Menurut Winarno (2002) kekenyalan terbentuk pada saat pemasakan, dimana protein akan mengalami denaturasi dan molekul-molekulnya mengembang. Menurut Falahudin (2013), lemak memegang peranan penting dalam pembentukan emulsi adonan yang selanjutnya dapat mempengaruhi kekenyalan.

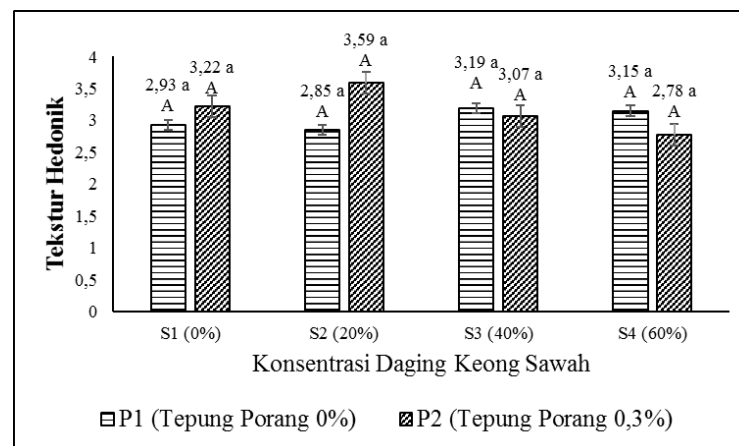

Gambar 7. Grafik Interaksi Pengaruh
Konsentrasi Daging Keong Sawah
dan Konsentrasi Tepung Porang
terhadap Tekstur Bakso Keong
Sawah Secara Hedonik

\section{KESIMPULAN}

Berdasarkan hasil analisis dan pembahasan dapat disimpulkan bahwa konsentrasi daging keong sawah berpengaruh nyata terhadap mutu fisik (tekstur, warna $(L, a$ dan b)), dan mutu sensoris (warna dan tekstur secara hedonik). Konsentrasi tepung porang berpengaruh nyata terhadap mutu fisik (warna $\mathrm{L}$ dan b). Interaksi perlakuan antara konsentrasi daging keong sawah dan konsentrasi tepung porang berpengaruh nyata terhadap mutu fisik (warna a dan b) dan mutu sensoris tekstur secara hedonik. Perlakuan konsentrasi daging keong sawah $20 \%$ dengan 
Versi Online:

http://www.profood.unram.ac.id/index.php/profood e-ISSN: 2443-3446

penambahan tepung porang $0,3 \%$ merupakan perlakuan yang terbaik. Nilai mutu fisik diperlakuan terbaik untuk tekstur 3,38 N, warna L 42,46, warna a 2,92 dan warna b 16,31 . Nilai sensoris warna agak suka dan tekstur suka.

\section{DAFTAR PUSTAKA}

Akesowan, A., 2007. Effect of a Konjac Flour/Soy Protein Isolate Mixture on Reduced-Fat, Added Water Chiffon Cakes. Assumption Univ. J. Techno/11(1): 23-27.

Anggraeni, D.A., dan Ningtyas, S.B.W. dan D.W. 2014. Proporsi Tepung Porang (Amorphophallus muelleri Blume): Tepung Maizena terhadap Karakteristik Sosis Ayam. J. Pangan dan Agroindustri 2 (3): 214-223.

Apandi, I., Restuhadi, F., dan Yusmarini. 2016. Analisis Pemetaan Kesukaan Konsumen (Consumer's Preference Mapping) terhadap Atribut Sensori Produk Soygurt Dikalangan Mahasiswa Fakultas Pertanian Universitas Riau. J. Faperta 3(2): 1-16.

Cato, L., Rosyidi, D. dan dan Imam Thohari. 2015. Pengaruh Substitusi Tepung Porang (Amorphophallus oncophyllus) pada Tepung Tapioka terhadap Kadar Air, Protein, Lemak, Rasa dan Tekstur Nugget Ayam Lione. J. Ternak Trop 16(1): 15-23.

Engelen, A. 2018. Analisis Kekerasan, Kadar Air, Warna dan Sifat Sensori Pada Pembuatan Keripik Daun Kelor. J. Agritech Sci 2(1): 10-15.

Falahudiin, A. 2013. Kajian Kekenyalan dan Kandungan Protein Bakso Menggunakan Campuran Daging Sapi dengan Tepung Jamur Tiram (Pleurotus ostreatus). J. IImu Pertanian dan Peternakan 1(2): 1-9.

Glicksman, M. 1969. Gum Technology in Food Industry. Academic Press. New York.

Gunawan, L. 2013. Analisa Perbandingan Kualitas Fisik Daging Sapi Impor dan Daging Sapi Lokal. J. Hosp. dan Manaj. Jasa 1(1): 146-166.

Hardoko, H., Sasmito, B.B., Puspitasari, Y.E., dan Lilyani, N. 2018. Konversi Ikan Asin Menjadi Nugget Berserat Pangan dengan Mencampurkan Ampas Tahu dan Beberapa Jenis Binder. J. Pengolahan Hasil Perikanan. Indones 21(1): 54.
Pro Food (Jurnal Ilmu dan Teknologi Pangan)

Vol 5 No. 2 November 2019

ISSN: 2443-1095

Hermanianto, J \& R. Y. Andayani. 2002. Studi Perilaku Konsumen dan Identifikasi Parameter Bakso Sapi Berdasarkan Preferensi Konsumen Di Wilayah DKI Jakarta. Retrieved from Jurnal Teknologi Industri Pangan 13(1): 1-10.

Herutami, R. 2002. Aplikasi Gelatin Tipe A Dalam Pembuatan Permen Jelly Mangga (Mangifera indica L). Skripsi. Fakultas Teknologi Pertanian. Institut Pertanian Bogor. Bogor.

Hill, G. E. dan K. J. MCGRAW. 2006. Bird Coloration, Vol. 1. Mechanisms and Measurments. Harvard University Press. Boston. USA.

Huang, L., Takahashi, R., Kobayashi, S., Kawase, T. \& Nishinari, K. 2002. Gelation Behavior of Native and Acetylated Konjac Glucomannan. J. of Biomacromolecules 3(1): 1296-1303.

Kusnandar, F. 2010. Kimia Pangan: Komponen Makro. Dian Rakyat. Jakarta.

Muchtadi, D. 2010. Teknk Evaluasi Nilai Gizi Protein. Alfabeta. Bandung.

Oktasari, N. 2015. Pemanfaatan Keong Sawah (Pila ampullacea) pada Pembuatan Nugget Sebagai Alternatif Makanan Berprotein Tinggi di Desa Jurug Kecamatan Mojosongo Kabupaten Boyolali. Skripsi. Universitas Negeri Semarang. Semarang.

Panjaitan, Tiurma W. S., Dwi A.R. dan Richardus W. 2017. Aspek Mutu dan Tingkat Kesukaan Konsumen terhadap Produk Mie Basah dengan Substitusi Tepung Porang. J. Tek. Industri HEURISTIC 14(1): 1-16.

Permatasari, N.E., dan Adi, A.C. 2018. Daya Terima Dan Kandungan Gizi (Energi, Protein) Gyoza Yang Disubstitusi Keong Sawah (Pila ampullacea) Dan Puree Kelor (Moringa oleifera). Media Gizi Indonesia 13(1): 62.

Purnamasari, E., A. M. Legowo dan V. P. Bintoro. 2011. Sifat Warna dan Kimia Daging Ayam Cemani yang Direndam dalam Larutan Asam Sitrat. J. Teknologi Peternakan dan Veteriner 1(1): 806-814.

Putri, A. F. E. 2009. Sifat fisik dan organoleptik Sosis Babi pada Lama Postmortem yang Berbeda dengan Penambahan karagenan. Skripsi. Fakultas Peternakan Institut 
Versi Online:

http://www.profood. unram.ac.id/index.php/profood e-ISSN: 2443-3446

Pertanian Bogor. Bogor.

Rahmi, S. L., Fitri T. dan Selvia A. 2012. Pengaruh Penambahan Gelatin terhadap Pembuatan Permen Jelly dari Bunga Rosella (Hibiscus sabdariffa Linn). J. Penelitian Universitas Jambi 14(1): 37-44.

Ramdani, B. K. 2018. Pengaruh Konsentrasi Tepung Porang Terhadap Sifat Fisikokimia dan Organoleptik Fruit Leather PisangNaga Merah. Artikel IImiah 1-13.

Rauf, S. 2011. Daya Terima Dan Kandungan Protein Bakso Keong Sawah (Pomacea canaliculata lamarck). Media Gizi Pangan.

Risjad, R V. 1996. Studi Ketersediaan dan Pemanfaatan Keong Gondang (Pila scutata Moussam) dan Tutut (Bellamya javanicus) sebagai Sumber Protein Hewani. Skripsi. Fakultas Pertanian, Institut Pertanian Bogor. Bogor.

Romans, J. R., Castello, W.J., Carlson, C.W., Greaser, M.L. and Jones, K.W. 1994. The Meat We Eat. Third Edition, Danville: Interstate Publisher Inc.

Sidik, W.D. 2013. Pengaruh Substitusi Jamur Kuping Putih dan Jenis Pati Terhadap Kualitas Bakso Sapi dengan Isian Saus. Food Sci. Culin. Educ. J. 2(2): 63-71.

Silaban, R. 2009 Studi Pemanfaatan Getah Buah Mangga Untuk Melunakkan Daging. Media Prima Sains 1(1): 1-12.

SNI. 2014. Standar Nasional Indonesia 3818:2014 Bakso Daging. 2.

Sood, N., W. L. Baker and C. I. Coleman. 2008. Effect of Glucomannan on plasma lipid and Glucose Concentrations, Body Weight and Bloos Pressure: Systematic Review and Meta-Analysis. The American Journal of Clinical Nutrition.

Sudarwati. 2007. Pembuatan bakso daging sapi dengan penambahan kitosan. Skripsi Sarjara. Fakultas Pertanian. USU.

Sudrajat, G. 2007. Sifat Fisik dan Organoleptik Bakso Daging Sapi dan Daging Kerbau dengan Penambahan Karagenan dan Khitosan. Skripsi. Fakultas Pertanian, Institut Pertanian Bogor. Bogor.

Sugiarso, A. dan Fithri C. N. 2015. Pembuatan Minuman Jeli Murbei (Morus alba L.) dengan Pemanfaatan Tepung Porang (A.muelleri Blume) Sebagai Pensubtitusi
Pro Food (Jurnal Ilmu dan Teknologi Pangan)

Vol 5 No. 2 November 2019

ISSN: 2443-1095

Karagenan. J. Pangan dan Agroindustri 3(2): 443-452.

Sumarwoto. 2005. Iles-iles (Amorphophallus muelleri Blume); Deskripsi dan Sifat-Sifat Lainnya. Biodiversitas 6(3): 185-190.

Suwati, A. 2007. Proporsi Penambahan Tepung Tapioka dan Tepung Terigu serta Pengaruhnya Terhadap Sifat Kimia dan Organoleptik Bakso Ikan Tongkol. Skripsi Sarjana. Fakultas Pertanian. Universitas Muhammadiyah. Mataram.

Tanjung, I.S., Prastiwi, D.A., Nurmaghfiroh, Wulandari, R., \& Kurniawan, E.K. 2013. Bakso Tutut: Sumber Protein Baru Penggemar Bakso. Laporan akhir program kreativitas mahasiswa. IPB. Bogor.

Wibowo, S. 2006. Pembuatan Bakso Ikan dan Bakso Daging. Penebar Swadaya. Jakarta.

Widjanarko. 2014. Pengaruh Lama Penggilingan Tepung Porang (Amorphophallus muelleri Blume) dengan Metode Ball Mill (Cyclone Separator) terhadap Sifat Fisik dan Kimia Tepung Porang.

Winarno, F. G. 2002. Kimia Pangan dan Gizi. Penerbit PT. Gramedia Pustaka Utama. Jakarta.

Yuwono, S.S. dan Susanto, T. 1998. Pengujian Fisik Pangan. Jurusan Teknologi Hasil Pertanian.Universitas Brawijaya. 